\title{
Acacia cyclops A. Cunn. ex G. Don (Leguminosae) in Italy: first cases of naturalization
}

\author{
Salvatore Pasta, Emilio Badalamenti \& Tommaso La Mantia \\ Facoltà di Agraria, Università di Palermo, Dipartimento DEMETRA, Viale delle Scienze, Edificio 4, Ingresso H, I-90128, Palermo, Italy \\ salvatore.pasta@alice.it; emilio.badalamenti@unipa.it; tommaso.lamantia@unipa.it.
}

\begin{abstract}
Pasta, S., Badalamenti, E. \& La Mantia, T. 2012. Acacia cyclops A. Cunn. ex G. Don (Leguminosae) in Italy: first cases of naturalization. Anales Jard. Bot. Madrid 69(2): 193-200.

The first two cases of naturalization of Acacia cyclops are reported for Italy. Young trees were observed growing in the wild some 15 years ago on Linosa (Pelagie Islands, Strait of Sicily). A decade later, this alien plant should no longer be considered as a casual, since a very intensive process of self-sown regeneration has been observed in some plantations on Lampedusa, the major island of the same Archipelago. The available literature suggests the need for careful monitoring of the ongoing invasion process, as $A$. cyclops has already shown a very invasive behaviour elsewhere within Mediterranean-type biomes due to its ability to withstand high environmental stresses. As migrating birds are suspected to have played an important role in facilitating the arrival of $A$. cyclops, further propagules are likely to reach the islands in the future. We recommend that new plantations of $A$. cyclops should be forbidden, but that extant naturalized populations should be managed instead of eradicating them. In fact, the effect of Acacia plantations warrants investigation at different scales in order to assess their impact on local plant-diversity and ecological succession processes.
\end{abstract}

Keywords: Alien plants, Mediterranean, Biological invasions, island vascular flora.

\section{INTRODUCTION}

\section{Plant invasion within the Mediterranean}

Biological invasions are widely recognized to be among the most critical factors affecting native ecosystems, by altering their structure and functioning, and are one of the main threats to biodiversity on a global scale (Chapin \& al., 2000; Sala \& al., 2000). Although the number of invasive alien species (IAS sensu Pyšek \& al., 2004) represents only a small fraction of introduced species, their ecological and economic impacts are significant and long lasting. A number of factors make Mediterranean-type ecosystems (MTEs, i.e. Mediterranean Basin, California, Central Chile, the Cape Region of South Africa and S-SW Australia) particularly prone to invasions (Brunel, 2005), as has been shown dramatically in South Africa and in SW Australia (e.g. Henderson, 2001). Despite a significant and intense anthropic pressure over most of its territory, the Mediterranean Basin is still characterized by a striking species and community richness. Moreover, due to its remarkable environmental heterogeneity, the Mediterranean Basin hosts a particularly diversified flora concentrated in a relatively small area (Heywood, 1995), such that although representing only $1.6 \%$ of the earth's surface, about 25,000 plant species (i.e. approximately $10 \%$ of the World's vascular flora: Cowling \& al., 1996) thrive there. The highest levels of

\section{Resumen}

Pasta, S., Badalamenti, E. \& La Mantia, T. 2012. Acacia cyclops A. Cunn. ex G. Don (Leguminosae) en Italia: primeros casos de naturalización. Anales Jard. Bot. Madrid 69(2): 193-200 (en inglés).

Se muestran los dos primeros casos de naturalización de Acacia cyclops para el territorio italiano. Se observó que las plántulas de este arbol crecen en forma silvestre hace unos 15 años en Linosa (islas Pelagias, estrecho de Sicilia). Una década después, ya no puede ser considerada una xenófita casual ya que se observó una regeneración muy intensa en algunos proyectos de reforestación en Lampedusa, la isla más grande del mismo archipiélago. Publicaciones anteriores sugieren la necesidad de un monitoreo cuidadoso del proceso de invasión en curso, ya que $A$. cyclops ha expresado un comportamiento altamente invasivo en otros biomas de tipo mediterráneo, debido a su alta tolerancia al estrés ambiental. Dado que se sospecha que las aves migratorias han jugado un papel importante en la llegada de A. cyclops, es probable que en el futuro otros propágulos lleguen a las islas Pelagias. Se recomienda la prohibición de nuevas plantas, aunque también el manejo de poblaciones artificiales ya presentes en vez de su erradicación. El efecto de la forestación con A. cyclops, de hecho, merece ser investigado a diferentes escalas, a fin de aclarar su impacto tanto en la diversidad florística local como en los procesos de sucesión ecológica.

Palabras clave: Xenófitas, Mediterráneo, invasiones biológicas, flora vascular insular.

endemism have been recorded on islands (Heywood, 2011), where the ecological threat posed by alien invasive species seems to be higher than in adjacent mainland areas (Gimeno $\&$ al., 2006; Hulme \& al., 2007). It has been suggested that island biota appear more vulnerable to invasions due to the presence of empty niches in unsaturated communities, the absence of key functional groups, and a generally lower competitive ability of the native species (Hulme, 2004). Indeed, more than 350 naturalized alien plants were found on only five of the major Mediterranean islands by Lloret \& al. (2005), justifying Hulme \& al. (2007), who pointed out that "the islands of the Mediterranean Basin probably represent some of the ecosystems globally most at risk from invasive species". This worrisome situation has a historical explanation, because the Mediterranean Basin has a long history of trade links with many regions of the world, and many plants were introduced over the centuries, mainly for forestry, ornamental and agricultural purposes, thereby increasing the likely arrival of invasive species (Hulme \& al., 2007; Lambdon \& al., 2008a). During the last century, the rate of introduction of invasive species has dramatically increased, and a similar trend is expected to maintain over the next decades (Lambdon \& al., 2008a). In addition, human pressure on Mediterranean environments has radically transformed the natural landscape and vegetation communities, particularly in coastal and upland

\footnotetext{
* Corresponding author.
} 
areas (Gritti \& al., 2006; Heywood, 2011). Land-use change (e.g. urbanization, exploitation of coastal areas, agricultural development, afforestation, etc.), together with the increased intensity and frequency of natural disturbance regimes, have markedly changed resource availability (light, water and nutrients), often favouring the establishment and the invasive success of allochthonous species (Lambdon \& al., 2008b). As most of these species are strictly confined to frequently disturbed and anthropogenic sites, such as ruderal habitats, roadsides and waste places (Arianoutsou \& al., 2010; Affre \& al., 2010), many native ruderal annuals, a significant component of endemic Mediterranean plants (Heywood, 1995), might be seriously threatened by the spread of invasives. Among natural habitats, wetlands and coastal areas are relatively richer in IAS than other habitats, suggesting that those habitats may suffer a greater impact (Chytrý \& al., 2009; Arianoutsou \& al., 2010). In contrast, Mediterranean mature and stable woodlands, dominated by evergreen shrubs and trees, seem to be quite resistant to invasion (Affre \& al., 2010; Arianoutsou \& al., 2010;), although human disturbance, such as wildfires or silvicultural interventions, may alter canopy structure and so understory light availability, thus allowing the establishment of heliophilous tree species (Constán-Nava \& al., 2010; Badalamenti \& al., 2012); invasions by such species have already caused a reduction in species richness and a significant alteration of functioning of Mediterranean ecosystems (Vilà \& al., 2006; Traveset \& al., 2008). However, the major ecological impacts caused by IAS have probably yet to be realized, because a worsening of the current situation is expected, both in terms of number and spread, and conse- quently of their likely damaging effects. Indeed, increasing anthropogenic pressure, together with the impact of climate change, could exacerbate the likelihood and the rate of spread of some IAS, thereby increasing habitat vulnerability or IAS competitive ability or both (Gritti \& al., 2006; Affre $\&$ al., 2010). According to global scenarios, biodiversity in Mediterranean ecosystems could be threatened by IAS to a greater extent than in any other terrestrial biome during this century (Sala \& al., 2000). The development of appropriate strategies in the Mediterranean Basin is urgently needed to tackle the IAS problem, which is increasingly becoming a priority in management policies of natural and semi-natural habitats.

\section{The invasion of Acacia species in Western Mediterranean}

With regard to the genus Acacia, at least 23 species figure among the most aggressive invaders of Mediterranean-type ecosystems worldwide, and 14 of them (Table 1) have been particularly successful in colonizing southern European countries (Lambdon \& al., 2008b).

After successful establishment, several wattle species have proved capable of altering the community structure (Marchante \& al., 2008; Werner \& al., 2008), not only because of their marked ability to sequester water resources (Rascher \& al., 2011), but also because their nitrogen fixing activity (Hellmann \& al., 2011), and the release of allelopathic compounds (Hussain \& al., 2011) that completely alter the biochemical and microbiological characteristics of the soils of the invaded ecosystems.

As a consequence, special efforts have been made to fore-

Table 1. An overview of the 14 recorded as invasive Acacia species within Mediterranean countries and their: present status in Sicily.

\begin{tabular}{|c|c|c|c|c|c|c|c|c|}
\hline Taxon & Origin & $\begin{array}{l}\text { Record of } \\
\text { cultivation }\end{array}$ & $\begin{array}{l}\text { Date of } \\
\text { naturalization }\end{array}$ & S\&a & T\&B & ILDIS & CG & $R \& R$ \\
\hline A. baileyana F. Müller & SE Australia & 1910 (Ostinelli) & n.d.a. & + & - & - & - & - \\
\hline A. cyclops G. Don & SW Australia & $\begin{array}{l}\text { c. } 1910 \\
\text { (Borzì \& al., 1911) }\end{array}$ & 2012 (this paper) & + & inv & - & - & - \\
\hline A. dealbata Link & SE Australia \& Tasmania & 1903 (Zodda) & n.d.a. & - & inv & - & inv & + \\
\hline A. decurrens Willd. & SE Australia & 1821 (Gussone) & n.d.a. & + & - & - & - & - \\
\hline A. farnesiana (L.) Willd. & Santo Domingo & $\mathrm{XVII}$ century & 1968 (Franco) & + & - & + & cas & - \\
\hline A. karroo Hayne & S Africa & $\begin{array}{l}1821 \text { (Gussone, } \\
\text { sub } A \text {. horrida) }\end{array}$ & $\begin{array}{l}1957 \text { (Romeo, } \\
\text { sub A. horrida) }\end{array}$ & + & inv & + & nat & - \\
\hline $\begin{array}{l}\text { A. longifolia (Andrews) } \\
\text { Willd. }\end{array}$ & SE Australia & 1821 (Gussone) & 1909 (Trinchieri) & + & inv & - & nat & + \\
\hline A. mearnsii De Wild. & SE Australia \& Tasmania & 1993 (Paiero \& al.) & n.d.a. & + & inv & - & inv & + \\
\hline A. melanoxylon R. Br. & SE Australia \& Tasmania & 1903 (Zodda) & 1909 (Tinchieri) & + & inv & - & cas & + \\
\hline A. pycnantha Benth. & SE Australia & $\begin{array}{l}\text { c. } 1910 \\
\text { (Borzì \& al., 1911) }\end{array}$ & 1977 (Lumini, 1978) & + & inv & - & cas & - \\
\hline A. retinodes Schldl. & SE Australia \& Tasmania & 1910 (Ostinelli) & n.d.a. & + & inv & - & inv & - \\
\hline $\begin{array}{l}\text { A. saligna (Labill.) } \\
\text { H.L. Wendl. }\end{array}$ & SW Australia & $\begin{array}{l}1903 \text { (Zodda, sub A. } \\
\text { cyanophylla Lindley) }\end{array}$ & $\begin{array}{l}1968 \text { (Franco, sub } \\
\text { A. cyanophylla Lindley) }\end{array}$ & + & inv & + & inv & - \\
\hline $\begin{array}{l}\text { A. sophorae } \\
\text { (Labill.) R. Br. }\end{array}$ & SE Australia & n.d.a. & n.d.a. & + & - & - & - & - \\
\hline $\begin{array}{l}\text { A. verticillata (L'Hér.) } \\
\text { Willd. }\end{array}$ & Australia \& Tasmania & 1821 (Gussone) & n.d.a. & + & - & - & - & - \\
\hline
\end{tabular}

S\&a, Naturalized in S Europe according to Sheppard \& al. (2006); T\&B, species behaving as invasive weeds in at least one Mediterranean country according to Thomson \& Brundu (2010); ILDIS, presence in Sicily according to ILDIS (2010); CG, mentioned in the most recent check-list of Italian alien plants (Celesti-Grapow \& al., 2010); R\&R, widespread xenophytes showing weedy behaviour in Europe according to Richardson \& Rejmánek (2011); cas, casual; nat, naturalized; inv, invasive; n.d.a., no data available. 
cast or avoid the risks of invasion of the most dangerous $A c a-$ cia species, such as A. mearnsii (Lowe \& al., 2000), A. longifolia (Marchante \& al., 2008), A. saligna (Crosti \& al., 2010) and A. dealbata (Lorenzo \& al., 2010).

\section{Global distribution and ecology of Acacia cyclops}

Easy to recognize by the conspicuous dark orange-red eyemimicking aril surrounding the seed (Kodela \& Tindale, 2001), within its native range Acacia cyclops grows along the coasts of W and S Australia, which are mostly characterized by a Mediterranean-type climate (Gill, 1985). Widely cultivated in many warm-temperate and subtropical regions of the world, Acacia cyclops has also been used for afforestation in semiarid regions because of its drought and salt tolerance (National Research Council, 1980), and it is able to establish in areas with only $250-300 \mathrm{~mm}$ of annual rainfall (National Research Council, 1980; Gill, 1985). It has been introduced as an ornamental plant or for afforestation purposes in the Mediterranean Basin, where it is naturalized in northern Africa (Vilà \& al., 1999), along the coasts of S Spain (Paiva, 1999) and W Portugal, where it behaves as an invasive environmental weed (Marchante \& al., 2008). In recent years it has also achieved a very rapid spread in the Canary Islands (Verloove \& Reyes-Betancort, 2011). In Italy, Acacia cyclops commonly named red-eyed wattle - does not figure in the most recent alien plant inventories (e.g. Celesti-Grapow \& al., 2010).

Currently, A. cyclops is the most widespread and dangerous woody invader in the Cape Province, South Africa (Whibley \& Symon, 1992; Richardson \& al., 1996), where it may form dense, impenetrable stands invading and displacing indigenous flora. Once established over large areas, the species is difficult to remove or replace, especially after a consistent seed bank in the soil has been formed (Milton \& Hall, 1981). Attempts to control it have included the use of both herbicides and biocontrol agents (Henderson, 2001), as well as prescribed burning, alone or combined with felling (Holmes, 1989). However, two insects have recently provided a significant reduction in Acacia cyclops seed production (Impson \& al., 2004; Post \& al., 2010), and biological control appears to be the most effective and cost-saving method for curbing the Acacias reproductive potential and related invasiveness (Richardson \& Kluge, 2008). Because of the substantial absence of vegetative propagation (Gill, 1985; Gibson \& al., 2011), A. cyclops establishment and invasive success is strongly dependant on a copious production of viable seeds and their subsequent dispersal (Milton \& Hall, 1981; Holmes, 1988). In particular, its seeds with attractive arils are well adapted for bird dispersal whilst they are retained in the canopy (Glyphis \& al., 1981), but once the seeds have fallen to the ground, ants and small rodents may also spread them or carry them into the deeper soil layers, thus increasing the likelihood of their being added to the soil seed-bank (Holmes, 1989; Richardson \& Kluge, 2008).

Unlike other well-known invasive Acacias, such as Acacia saligna (Labill.) H.L. Wendl. and A. longifolia (Andrews) Willd., A. cyclops seed germination does not seem to be significantly enhanced by very high temperatures or by fire (Jef- fery \& al., 1988; Holmes, 1989), rather it depends upon chemical scarification, notably after the passage through the gut of birds, or to only moderate heating in order to break dormancy (Glyphis \& al., 1981; Gill, 1985; Jeffery \& al., 1988). Its known ability to regenerate prolifically following fire from the huge seed-bank stored in the soil (Milton \& Hall, 1981), and its dominance over frequently burned areas in South Africa (Glyphis \& al., 1981; Richardson \& al., 1996), is therefore mainly due to the reduction of interspecific competition caused by fire rather than to a higher seedling emergence and establishment. Moreover, the considerable annual seed rain (nearly 2,000 seeds/ $\mathrm{m}^{2}$ ), together with the high percentage of seed physical dormancy (Milton \& Hall, 1981), indicate that this species rapidly accumulates and stores its seeds in the soil. But since only $20-40 \%$ of seeds remain dormant in the soil after one year (Holmes \& Moll, 1980), due to germination or decay, the time to produce an effective soil seed-bank takes 11 years (Holmes, 1989). From that moment on, the seed density in the soil stabilizes, and may range from 1,400 to 7,800 seeds $/ \mathrm{m}^{2}$ (Holmes \& al., 1987; Holmes, 1989).

The South African invasion case clearly demonstrates that an $A$. cyclops-dominated community is persistent (Richardson \& Cowling, 1992) and that this species has a great ability to expand out of its native range (Higgins \& al., 2000). In addition, its definitive establishment results in constant, large inputs of nitrogen-rich litter because this xenophyte produces more litter with a higher leaf $\mathrm{N}$ concentration than native fynbos shrubs, increasing not only total soil $\mathrm{N}$ and organic matter (Witkowski, 1991a), but also net $\mathrm{N}$ mineralization rates (Stock \& al., 1995). In many nutrient-limited ecosystems this evergreen shrub shows a great competitive ability, a higher relative growth rate (Witkowski, 1991b); furthermore, a better acquisition of water resources (Morris \& al., 2011) allows it to out-compete native coexisting species.

\section{MATERIAL AND METHODS}

In order to provide a preliminary evaluation of $A$. cyclops reproductive success, we measured the percentage cover of seedlings (bearing the juvenile character of compound leaves) and saplings (in which the compound leaves have been replaced by phyllodes) under twenty mature plants at Taccio Vecchio, where an intense self-regeneration rate had been observed. The same plants were used to check the effect of redeyed wattle on the recruitment and establishment of native woody species. We also carried out phytosociological relevés (Braun-Blanquet, 1932) in two $5 \mathrm{~m}^{2}$-wide circular concentric areas around the stem, the first under tree canopy $(\mathrm{u})$, the second outside the canopy (o), i.e. in open areas adjacent to the investigated plants. In order to test any facilitating effect of $A$. cyclops, the total woody (subshrubs, shrubs and trees) species richness, and plant and litter percentage cover were recorded, and also the number of species typical of garrigue, maquis and forest communities, except $A$. cyclops.

\section{RESULTS AND DISCUSSION}

Our report represents the first case-study of naturalization of Acacia cyclops in Italy. On Lampedusa (Strait of Sicily, Pelagie Islands), interviews with local forest agents, land own- 


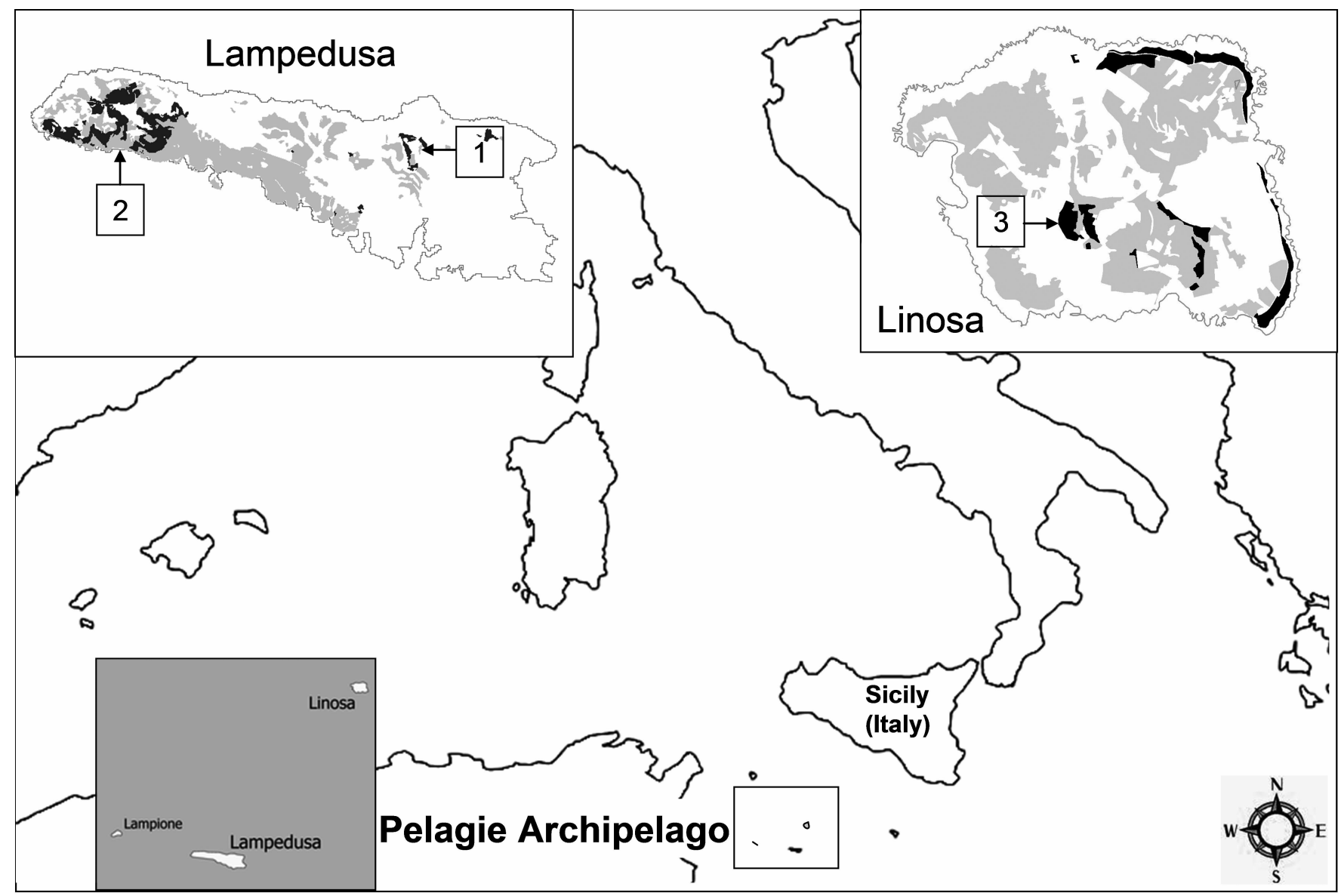

Fig. 1. Location of Pelagie Archipelago, Lampedusa (Strait of Sicily, Southern Italy), and Acacia cyclops study areas (boxes: 1, Taccio Vecchio; 2 , Sanguedolce, Lampedusa. 3, Monte Bandiera, Linosa). The black areas represent the distribution of the afforestations while the light-grey ones represent the distribution of garrigue communities.

ers and shepherds allowed us to retrace the intriguing history of the local naturalization of $A$. cyclops. The first red-eyed wattle was observed growing wild in the 70 s near a private orchard at Contrada Sanguedolce. Since no one had ever seen the plant before, and the owner testified that he had not planted it (R. Almanzo, pers. comm.) seeds were probably introduced by birds migrating from Tunisia. In following years, the forest agent Calogero Mantisi collected seeds from the first settler plants to become established, sowed them in the nursery on Lampedusa, and sent some young plants to Linosa (Mantisi, 2001). Subsequently, in August 1998, A. cyclops was observed to produce seeds and had become established within a private camping area on Linosa (Strait of Sicily, Pelagie Islands) by S. Pasta and S. Mattana. A decade later (June 2009 according to T. La Mantia and S. Pasta), seedlings of $A$. cyclops were also observed growing within the afforested areas on Lampedusa, the major island of the same Archipelago (Fig. 1).

Intense regeneration by self-sowing has been observed (Fig. 2) in Contrada Sanguedolce (35'31'19'”N, 12³2'35'”, $97 \mathrm{~m}$ a.s.1.), and subsequently (March, 2012) in Contrada Tac-

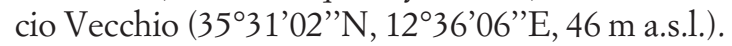

In recent years a significant increase of the number of seedlings, saplings and young trees has been recorded both on Lampedusa and Linosa; Effectively, the area colonized by
A. cyclops is about 6 ha on Lampedusa ( 5 ha in Contrada Taccio Vecchio +1 ha in Contrada Sanguedolce) and about 0.3 ha at Linosa. Although the most intense renewal and spread of the invading species has been recorded within afforested

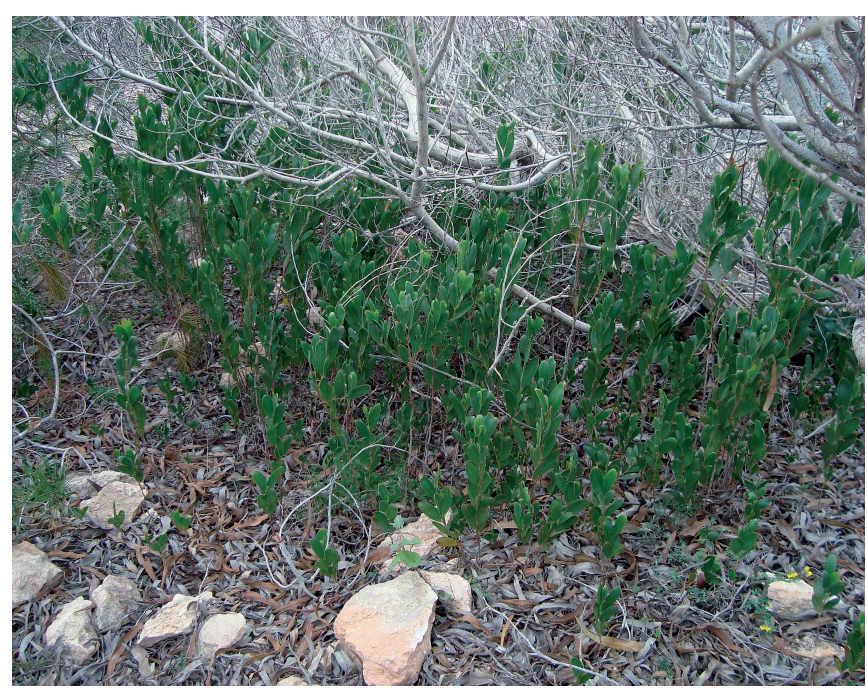

Fig. 2. Lampedusa, Locality Taccio Vecchio: vigorous germination under Acacia cyclops canopy. 
areas, the first attempts to spread out of the artificial plantation limits were observed since 2008. This success may be enhanced by local climate, which matches very well $A$. cyclops requirements: local mean yearly temperature is about $19^{\circ} \mathrm{C}$, while the mean annual rainfall, mostly concentrated between October and March, has decreased from 500 to about 300 $\mathrm{mm}$ in the last 150 years (La Mantia \& al., 2011).

Vegetation relevés (Table 2) reveal that total and subshrub species richness is higher within open habitats. On the other hand, all the other selected indicators (i.e. number of woody taxa, plant coverage, number of taxa referred to 'final' stages of succession) suggest a facilitation effect of $A$. cyclops plantations. In effect, all the seedlings and saplings of $A$. cyclops and of native woody species were found under adult $A$. cyclops trees.

Current investigations aim at understanding how planted A. cyclops improves renovation, in order to assess the role of different factors such as 1) increase of soil humidity due to litter coverage, 2) milder microclimatic conditions due to canopy shading, 3) nutrient input due to root symbiotic microorganisms and 4) nutrient input due to litter decomposition.

\section{CONCLUSIONS}

Owing to its strong drought tolerance, we assume that the expected reduction of rainfall in future decades will not hamper the local expansion of $A$. cyclops. On the contrary, more severe stresses may improve its competitive ability against native woody species. In fact, despite the presence of natural regeneration of Thymbra capitata (L.) Cav., Thymelaea hirsuta (L.) Endl., Pistacia lentiscus L., Prasium majus L., Asparagus aphyllus L. and Ceratonia siliqua L. (Fig.3), the overwhelming number of $A$. cyclops saplings, growing as clumps under the canopies of mother plants, suggests that facilitative conditions are much more favourable for self-regeneration than for the establishment of other co-existing species. Therefore, this alien plant may prevail over the native species listed above, at least in a long-term perspective. In fact, if we consider that Lampedusa and Linosa host many birds (Table 3 ) that are already known to play a role in the dispersal of $A$. cyclops in

Table 2. Vegetation characterization in studied populations. Life-forms according to Raunkiaer (1934).

\begin{tabular}{|c|c|c|}
\hline Parameter & $\begin{array}{c}\text { under } \\
\text { the canopy }\end{array}$ & $\begin{array}{l}\text { outside } \\
\text { the canopy }\end{array}$ \\
\hline A. cyclops seedlings coverage (\%) & 13 & 0 \\
\hline A. cyclops saplings coverage (\%) & 2.4 & 0 \\
\hline Species richness (= tot. nr. of taxa) & $10.4 \pm 6.0$ & $12.8 \pm 2.0$ \\
\hline Nr. of woody taxa $(P+N P+C h)$ & $6.0 \pm 3.0$ & $3.6 \pm 0.5$ \\
\hline Plant coverage (\%) & $33.0 \pm 18.0$ & $20.0 \pm 12.0$ \\
\hline Litter coverage (\%) & $64.0 \pm 28.0$ & 0 \\
\hline $\begin{array}{l}\text { Nr. of taxa typical to maquis and } \\
\text { forest communities (QI) }\end{array}$ & $2.6 \pm 2.0$ & 0 \\
\hline $\begin{array}{l}\text { Nr. of taxa typical to garrigue } \\
\text { communities }(\mathrm{C}-\mathrm{M})\end{array}$ & $2.2 \pm 1.0$ & $3.0 \pm 1.0$ \\
\hline
\end{tabular}

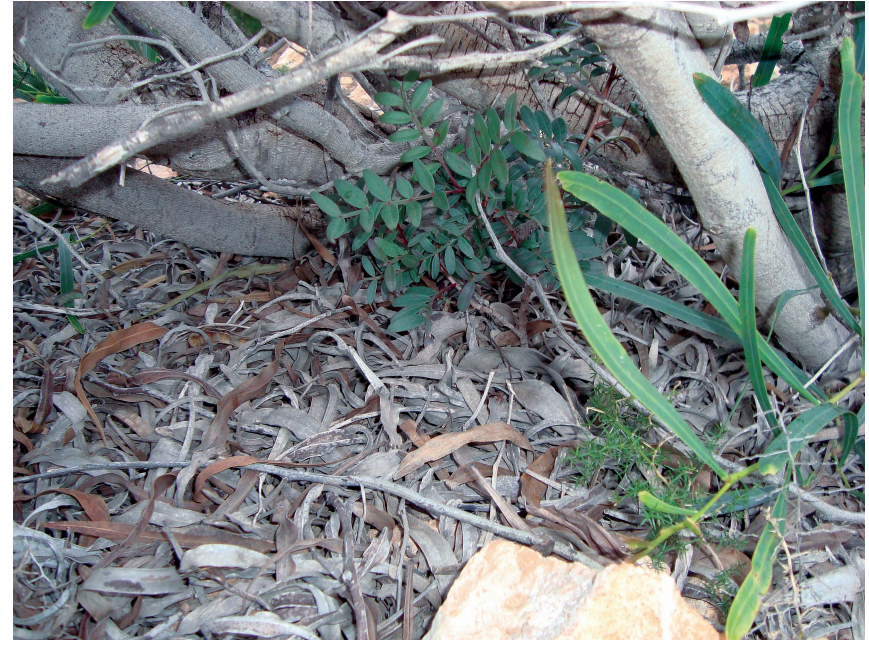

Fig. 3. Lampedusa, Locality Taccio Vecchio: saplings of Pistacia lentiscus under Acacia cyclops canopy.

South Africa (e.g. Streptopelia senegalensis and Sturnus vulgaris: Glyphis \& al., 1981), both these islets are likely to be prone to repeated introductions from N Africa, and to its spread in new suitable localities.

Recent investigations carried out on Lampedusa underline that the establishment of native woody species is a very difficult and slow process both in seminatural open habitats such as grasslands and garrigues (Pasta \& al., 2007) and in Pinus balepensis Mill. plantations (Pasta \& al., 2012). As a consequence, local plantations of short-lived Acacias were made in order to obtain ecological services (i.e. plant cover increase, soil protection and fertilization, microclimate amelioration, etc.) and to accelerate local succession, rather than to obtain wood or fodder. In this sense they have worked rather well, especially in the case of Acacia saligna, which up to now has not given any evidence of naturalization on Pelagie islands (Pasta \& La Mantia, 2001).

Notwithstanding the above-mentioned habitat modification provided by arboreal Leguminosae, and although up to now $A$. cyclops naturalization seems to be largely limited to forest plantations, a constant monitoring of its spread on Lampedusa and Linosa is needed because of its known invasiveness worldwide and because the Pelagie Islands host a very precious botanical heritage, with some 20 endemic and nearly one hundred other rare or threatened plants (La Mantia \& al., 2009).

Considering both the pros and cons of $A$. cyclops in Mediterranean environments, in our opinion the best way to deal with it is neither to directly favour introductions (planting new individuals should be forbidden) nor to eradicate its local populations, but to control and to manage them through selective cutting where the native shrub vegetation has developed. During last four decades Sicily experienced a dramatic rise of successful invasion events by other woody $\mathrm{Mi}$ mosoideae, such as Parkinsonia aculeata L. (Orlando \& Grisafi, 1977), Paraserianthes lophantha (Willd.) I.C. Nielsen (Villari \& Zaccone, 1999), Albizzia julibrissin (Willd.) Durazz. (Gueli \& Lo Giudice, 2005), Senegalia visco (Griseb.) Seigler \& Ebinger and Leucaena leucocephala (Lam.) De Wit 
Table 3. A comparison between the South African birds which act as Acacia cyclops seed dispersers and their potential substitutes on the Pelagian islands.

\begin{tabular}{ll}
\hline S Africa & Lampedusa and Linosa \\
\hline Passer melanura (Müller, 1776) & Passer hispaniolensis Temminck \\
& 1820 \\
Serinus sulphuratus Linnaeus & Serinus serinus Linnaeus 1766 \\
1766 & Carduelis cannabina Linnaeus \\
& 1758 \\
Streptopelia capicola & Streptopelia decaocto Frivaldszky \\
(Sundevall, 1857) & 1838 \\
Streptopelia senegalensis & Streptopelia senegalensis \\
(Linnaeus, 1766) & (Linnaeus, 1766) \\
Sturnus vulgaris Linnaeus 1758 & Sturnus vulgaris Linnaeus 1758 \\
\hline
\end{tabular}

subsp. glabrata (Rose) S. Zárate (Raimondo \& Domina, 2007).

\section{ACKNOWLEDGEMENTS}

This research was partially funded by Regione Siciliana, "Assessorato Risorse Agricole e Alimentari - Dipartimento Interventi Infrastrutturali, Area Studi e Programmazione", we are particularly grateful to F. Guaitoli and G. Matranga for supporting the Project "Analisi dei sistemi seminaturali e degli agro-ecosistemi nei sistemi insulari mediterranei: Isola di Lampedusa, pantani di Vendicari e sistemi agricoli regionali ad Alto Valore naturale (AVN)". Morevoer, it falls within the agreement between CNR (Consiglio Nazionale delle Ricerche) and FCT (Fundação para a Ciência e a Tecnologia) concerning the two-year research programme 2011/2012 "Valutazione della plasticità fenotipica di specie invasive del genere Acacia in ambienti mediterranei". We are particularly grateful to M. Lauteri (CNR-IBAF) and C.M.F. Máguas da Silva Hanson (University of Lisbon). We are indebted to Legambiente association, manager of "Isola di Lampedusa" Nature Reserve for material support during field research activity, funded by Assessorato Territorio ed Ambiente della Regione Sicilia. We also thank the Regional Department of Forests, in particular R. Almanzo, who suggested that Acacia cyclops probably colonized Pelagian islands exploiting bird dispersal. We managed to find most of the international papers on Acacia cyclops thanks to K. Dixon, P. Holmes, D.M. Richardson, D. Rokich and E. Witkowski; their kind help was very much appreciated.

\section{REFERENCES}

Affre, L., Suehs, C.M., Charpentier, S., Vilà, M., Brundu, G., Lambdon, P., Traveset, A. \& Hulme, P.E. 2010. Consistency in the habitat degree of invasion for three invasive plant species across Mediterranean islands. Biological Invasions 12: 2537-2548.

Arianoutsou, M., Delipetrou, P., Celesti-Grapow, L., Basnou, C., Bazos, I. Kokkoris, Y., Blasi, C. \& Vilà, M. 2010. Comparing naturalized alien plants and recipient habitats across an east-west gradient in the Mediterranean Basin. Journal of Biogeography 37: 1811-1823.

Badalamenti, E., Barone, E., Pasta, S., Sala, G. \& La Mantia, T. 2012. Ailanthus altissima (Mill.) Swingle (fam. Simaroubaceae) in Sicilia e cenni storici sulla sua introduzione in Italia. Il Naturalista siciliano, s. 4, 36(1): 117-164.

Borzì, A., Baldacci, A., Mattei, G.E., Tropea, A., Riccobono, V. \& Riccobono, A. 1911. Semina anni MCMXI quae pro mutua commutuatione offeruntur. Bollettino del Regio Orto Botanico e Giardino Coloniale di Palermo X (3, Appendix).

Braun-Blanquet, J. 1932. Plant sociology. McGraw-Hill, New York-London.

Brunel, S. (ed.). 2005. Proceedings of the International Workshop: Invasive plants in Mediterranean Type Regions of the World (Mèze, France, 25-27 May 2005): 1-287. Council of Europe Publishing, Strasbourg.

Celesti-Grapow, L., Pretto, F., Carli, E. \& Blasi, C. (eds.). 2010. Flora vascolare alloctona e invasiva delle regioni d'Italia: 1-208. Casa Editrice Università La Sapienza, Roma.

Chapin III, F.S., Zavaleta, E.S., Eviner, V.T., Naylor, R.L., Vitousek, P.M., Reynolds, H.L., Hooper, D.U., Lavorel, S., Sala, O.E., Hobbie, S.E.,
Mack, M.C. \& Díaz, S. 2000. Consequences of changing biodiversity. Nature 405: 234-242.

Chytrý, M., Pyšek, P., Wild, J., Pino, J., Maskell, LC. \& Vilá, M. 2009. European map of alien plant invasions based on the quantitative assessment across habitats. Diversity and Distributions 15: 98-107.

Constán-Nava, S., Bonet, A., Pastor, E. \& Lledó, M. 2010. Long-term control of the invasive tree Ailanthus altissima: Insights from Mediterranean protected forests. Forest Ecology and Management 260: 1058-1064.

Cowling, R.M., Rundel, P.W., Lamont, B.B., Kalin Arroyo, M. \& Arianoutsou, M. 1996. Plant diversity in mediterranean-climate regions. Trends in Ecology \& Evolution 11(9): 362-366.

Crosti, R., Cascone, C. \& Cipollaro, S. 2010. Use of a weed risk assessment for the Mediterranean region of Central Italy to prevent loss of functionality and biodiversity in agro-ecosystems. Biological Invasions 12: 1607 1616.

Franco (do Amaral), J. 1968. Acacia. In: Tutin, T.G., Heywood, V.H., Burges, N.A., Moore, D.M., Valentie, D.H., Walters, S.M. \& Webb, D.A. (eds.), Flora Europea Vol. 2: 84-85. Cambridge University Press, Cambridge.

Gibson, M.R., Richardson, D.M., Marchante, E., Marchante, H., Rodger, J.G., Stone, G.N.N., Byrne, M., Fuentes-Ramírez, A., George, N., Harris, C., Johnson, S.D., Le Roux, J.J., Miller, J.T., Murphy, D.J., Pauw, A., Prescott, M.N., Wandrag, E.M. \& Wilson, J.R.U. 2011. Reproductive biology of Australian acacias: important mediator of invasiveness? Diversity and Distributions 17: 911-933.

Gill, A.M. 1985. Acacia cyclops G. Don (Leguminosae: Mimosaceae) in Australia: distribution and dispersal. Journal of the Royal Society of Western Australia 67(2): 59-65.

Gimeno, I., Vilà, M. \& Hulme, P.E. 2006. Are islands more susceptible to plant invasion than continents? A test using Oxalis pes-caprae in the western Mediterranean. Journal of Biogeography 33: 1559-1565.

Glyphis, J.P., Milton, S.J. \& Siegfried, W.R. 1981. Dispersal of Acacia cyclops by birds. Oecologia 48(1): 138-141.

Gritti, E.S., Smith, B. \& Sykes, M.T. 2006. Vulnerability of Mediterranean Basin ecosystems to climate change and invasion by exotic plant species. Journal of Biogeography 33: 145-157.

Gueli, L. \& Lo Giudice, R. 2005. La vegetazione briofitica e vascolare dell'area urbana e territorio extraurbano di Militello in Val di Catania (Sicilia orientale). Quaderni di Botanica ambientale e applicata 15 (2004): 3 20.

Gussone, G., 1821. Catalogus plantarum quae asservantur in Regio Horto serenissimi Francisci Borbonii Principis Juventutis, in Boccadifalco, prope Panormum: 1-84. Typis Angeli Trani, Neapoli.

Hellmann, C., Sutter, R., Rascher, K.G., Máguas, C., Correia, O. \& Werner, C. 2011. Impact of an exotic $\mathrm{N}_{2}$-fixing Acacia on composition and $\mathrm{N}$ status of a native Mediterranean community. Acta Oecologica 37: 43-50.

Henderson, L. 2001. Alien weeds and invasive plants: A complete guide to declared weeds and invaders in South Africa. Paarl Printers, Cape Town.

Heywood, V.H. 1995. The Mediterranean flora in the context of world biodiversity. Ecologia Mediterranea 21: 11-18.

Heywood, V.H. 2011. An outline of the impacts of climate change on endangered species in the Mediterranean region. Il Naturalista siciliano, s. 4, 35(1): 107-119.

Higgins, S.I., Richardson, D.M. \& Cowling, R.M. 2000. Using a dynamic landscape model for planning the management of alien plant invasions. Ecological Applications 10: 1833-1848.

Holmes, P.M. 1988. Implications of alien Acacia seed bank viability and germination for clearing. South African Journal of Botany 54: 281-284.

Holmes, P.M. 1989. Effects of different clearing treatments on the seed-bank dynamics of an invasive Australian shrub, Acacia cyclops, in the southwestern Cape, South Africa. Forest Ecology and Management 28(1):33-46.

Holmes, P.M., Macdonald, I.A.W. \& Juritz, J. 1987. Effects of clearing treatment on seed banks of the invasive alien shrubs Acacia saligna and Acacia cyclops in the southern and south-western Cape, South Africa. Journal of Applied Ecology 24: 1045-1051.

Holmes, P.M. \& Moll, E.J. 1990. Effect of depth and duration of burial on alien Acacia saligna and Acacia cyclops seeds. South African Journal of Eco$\log y$ 1: 12-17.

Hulme, P.E. 2004. Invasions, islands and impacts: A Mediterranean perspective. In: Fernández-Palacios, J.M. \& Morici, C. (eds.), Island Ecology: 337 361. Asociación Española de Ecología Terrestre (AEET), La Laguna. 
Hulme, P.E., Brundu, G., Camarda, I., Dalias, P., Lambdon, P., Lloret, F., Médail, F., Moragues, E., Suehs, C.M., Traveset, A., Troumbis, A. \& Vilà, M. 2007. Assessing the risks to Mediterranean islands ecosystems from alien plant introductions. In: Tokarska-Guzik, B., Brock, J.H., Brundu, G., Child, L., Daehler, C.C. \& Pyšek, P. (eds.), Plant invasions: buman perception, ecological impacts and management: 39-56. Backhuys Publishers, Leiden.

Hussain, M.I., González, L. \& Reigosa, M.J. 2011. Allelopathic potential of Acacia melanoxylon on the germination and root growth of native species. Weed Biology and Management 11: 18-28.

ILDIS, 2010. ILDIS World data base of Legumes [http://www.ildis.org/].

Impson, F.A.C., Moran, V.C. \& Hoffmann, J.H. 2004. Biological control of an alien tree, Acacia cyclops, in South Africa: impact and dispersal of a seed-feeding weevil, Melanterius servulus. Biological Control 29:375-381.

Jeffery, D.J., Holmes, P.M. \& Rebelo, A.G. 1988. Effects of dry heat on seed germination in selected indigenous and alien legume species in South Africa. South African Journal of Botany 54(1): 28-34.

Kodela, P.G. \& Tindale, M.D. 2001. Mimosaceae (Acacia Part I). In: Flora of Australia 11A. CSIRO Publishing. Melbourne: 1-552.

La Mantia, T., Carimi, F., Di Lorenzo, R. \& Pasta, S. 2011. The agricultural heritage of Lampedusa (Pelagie Archipelago, South Italy) and its key role for cultivar and wildlife conservation. Italian Journal of Agronomy 6(2): 106-110.

La Mantia, T., Pasta, S. \& Rühl, J. 2009. Parte I - Quadro conoscitivo e proposte gestionali relative agli aspetti floristici, vegetazionali e agro-forestali. Piano di Gestione "Isole Pelagie" - SIC "Isole di Lampedusa e Lampione” POR 1999.IT.16.1.PO.011/1.11/11.2.9/0304, Legambiente-Comitato Regionale Siciliano e Dipartimento di Colture Arboree dell'Università di Palermo: 1-353. [http://www.artasicilia.eu/web/natura2000/ index.html].

Lambdon, P.W., Lloret, F. \& Hulme, P.E. 2008a. How do introduction characteristics influence the invasion success of Mediterranean alien plants? Perspectives in Plant Ecology, Evolution and Systematics 10: 143-159.

Lambdon, P.W., Pyšek, P., Başnou, C., Hejda, M., Arianoutsou, M., Essl, F., Jarošík, V., Pergl, J., Winter, M., Anastasiu, P., Andriopoulos, P., Bazos, I., Brundu, G., Celesti-Grapow, L., Chassot, P., Delipetrou, P., Josefsson, M., Kark, S., Klotz, S., Kokkoris, Y., Kühn, I., Marchante, H., Perglová, I., Pino, J., Vilà, M., Zikos, A., Roy, D. \& Hulme, P.E. 2008b. Alien flora of Europe: species diversity, temporal trends, geographical patterns and research needs. Preslia 80(2): 101-149.

Lloret, F., Médail, F., Brundu, G., Camarda, I., Moragues, E., Rita, J., Lambdon, P. \& Hulme, P.E. 2005. Species attributes and invasion success by alien plants on Mediterranean islands. Journal of Ecology 93: 512-520.

Lorenzo, P., González, L. \& Reigosa, M.J. 2010. The genus Acacia as invader: the characteristic case of Acacia dealbata Link in Europe. Annals of Forest Science 67(1): 101-111.

Lowe, S., Browne, M., Boudjelas., S. \& De Poorter, M. 2000. 100 of the World's worst invasive alien species: a selection from the Global Invasive Species Database. Invasive Species Specialist Group (ISSG), a specialist group of the Species Survival Commission (SSC) of the World Conservation Union (IUCN), University of Auckland, New Zealand. [http:// www.issg.org/database/species/reference_files/100English.pdf].

Lumini, L. 1978 (unpubl.). Ricerche sulla flora e la vegetazione dell'isola di Lampedusa (Is. Pelagie). Diplome Thesis, Florence University: 1-223.

Mantisi, C. 2001. Storia forestale dell'isola di Lampedusa con brevi note su Linosa e Lampione (Arcipelago delle Pelagie, Provincia di Agrigento). Collana "Sicilia Foreste" 13: 1-119. Azienda Foreste Demaniali della Regione Siciliana, Palermo.

Marchante, E., Freitas, H. \& Marchante, H. 2008. Guia Prático para a Identificação de Plantas Invasoras de Portugal Continental. Imprensa da Universidade de Coimbra, Coimbra.

Marchante, E., Kjøller, A., Struwe, S. \& Freitas, H. 2008. Short- and longterm impacts of Acacia longifolia invasion on the belowground processes of a Mediterranean coastal dune ecosystem. Applied Soil Ecology 40(2): 210-217.

Milton, S.J. \& Hall, A.V. 1981. Reproductive biology of Australian acacias in the south-western Cape province, South Africa. Transactions of the Royal Society of South Africa 44: 465-485.

Morris, T.L., Esler, K.J., Barger, N.N., Jacobs, S.M. \& Cramer, M.D. 2011. Ecophysiological traits associated with the competitive ability of invasive Australian acacias. Diversity and Distributions 17: 898-910.
National Research Council, 1980. Firewood crops: shrub and tree species for energy production. National Academy of Sciences, Washington D.C. [http://pdf.usaid.gov/pdf_docs/PNAAP479.pdf].

Orlando, A. \& Grisafi, F. 1977. Appunti per la flora esotica d'Italia. Informatore Botanico Italiano 9(2): 113-114.

Ostinelli, V. 1910. Villa Trabia: 1-251. Tip. Priulla, Palermo.

Paiero, P., Martini, F. \& Colpi, C. 1993. Leguminose arboree e arbustive in Italia: 1-191. Lint Ed., Trieste.

Paiva, J. 1999. Acacia Mill. In: Talavera, S., Aedo, C., Castroviejo, S., Romero, C., Sáez, L., Salgueiro, F.J. \& Velayos, M. (eds.), Flora Iberica, Vol. VII(1): 11-25. Real Jardín Botánico, CSIC, Madrid.

Pasta, S. 2001. Contributi alla conoscenza botanica delle isole minori circumsiciliane. I. Sintesi aggiornata delle conoscenze botaniche sull'Isola di Lampedusa finalizzata alla conservazione delle sue emergenze floristicovegetazionali. Il Naturalista siciliano, s. 4, 25: 19-70.

Pasta, S. \& La Mantia, T. 2001. Note sul paesaggio vegetale delle isole minori circumsiciliane. I. Consorzi forestali e preforestali dell'Isola di Lampedusa (AG) ed effetto degli impianti artificiali sulla vegetazione naturale. Il Naturalista siciliano, s. 4, 25: 71-89.

Pasta, S., La Mantia, T. \& Rühl, J. 2007. Analisi del dinamismo della vegetazione in un'area di saggio permanente negli ex-pascoli dell'isola di Lampedusa (Canale di Sicilia). $102^{\circ}$ Congresso nazionale della Società Botanica italiana (Palermo, 26-29 settembre 2007), riassunti: 271.

Pasta, S., La Mantia, T. \& Rühl, J. 2012. The impact of Pinus balepensis Mill. afforestation on Mediterranean spontaneous vegetation: do soil treatment and canopy cover matter? Journal of Forestry Research, Vol. 23(4): $517-$ 528.

Post, J.A., Kleinjan, C.A., Hoffmann, J.H. \& Impson, F.A.C. 2010. Biological control of Acacia cyclops in South Africa: The fundamental and realized host range of Dasineura dielsi (diptera: Cecidomyiidae). Biological Control 53(1): 68-75.

Py̌sek, P., Richardson, D.M., Rejmánek, M., Webster, G.L., Williamson, M. \& Kirschner, J. 2004. Alien plants in checklist and floras: towards better communication between taxonomists and ecologists. Taxon 53: 131-143.

Raimondo, F.M. \& Domina, G. 2007. Two new Mimosaceae naturalized in Italy. Flora Mediterranea 17: 209-216.

Raimondo, F.M., Domina, G., Spadaro, V. \& Aquila, G. 2005. Prospetto delle piante avventizie e spontaneizzate in Sicilia. Quaderni di Botanica ambientale e applicata 15 (2004): 153-164.

Rascher, K.G., Große-Stoltenberg, A., Máguas, C. \& Werner, C. 2011. Understory invasion by Acacia longifolia alters the water balance and carbon gain of a Mediterranean pine forest. Ecosystems DOI: 10.1007/s10021011-9453-7.

Raunkiær, C. 1934. The life forms of plants and statistical plant geography. Oxford University Press, Oxford.

Richardson, D.M. \& Cowling, R.M. 1992. Why is mountain fynbos invasible and which species invade? In: Van Wilgen, B.W. \& al. (eds.), Fire in South African Mountain Fynbos: Species, community and ecosystem response in Swartboskloof: 161-181. Springer-Verlag, Heidelberg.

Richardson, D.M. \& Kluge, R.L. 2008. Seed banks of invasive Australian Acacia species in South Africa: role in invasiveness and options for management. Perspectives in Plant Ecology, Evolution and Systematics 10: 161 177.

Richardson, D.M. \& Rejmánek, M. 2011. Trees and shrubs as invasive alien species - a global review. Diversity and Distributions 17: 788-809.

Richardson, D.M., van Wilgen, B.W., Higgins, S.I., Trinder-Smith, T.H., Cowling, R.M. \& McKelly, D.H. 1996. Current and future threats to biodiversity on the Cape Peninsula. Biodiversity and Conservation 5: 607-647.

Rivas-Martínez, S., Fernández-González, F., Loidi, J., Lousã, M. \& Penas, A. 2001. Syntaxonomical checklist of vascular plant communities of Spain and Portugal to association level. Itineraria Geobotanica 14:5-341.

Romeo, V. 1957. Le piante epifite dell'Orto Botanico di Messina. Nuovo Giornale Botanico Italiano, n.s., 64: 266-271.

Sala, O.E., Chapin III, F.S., Armesto, J.J., Berlow, E., Bloomfield, J., Dirzo, R., Huber-Sanwald, E., Huenneke, L.F., Jackson, R.B., Kinzig, A., Leemans, R., Lodge, D.M., Mooney, H.A., Oesterheld, M., Leroy Poff, N., Sykes, M.T., Walzer, B.H., Walzer, M. \& Wall, D.H. 2000. Global biodiversity scenarios for the year 2100. Science 287: 1770-1774.

Sheppard, A.W., Shaw, R.H. \& Sforza, R. 2006. Top 20 environmental weeds for classical biological control in Europe: a review of opportunities, regulations and other barriers to adoption. Weed Research 46: 93-117. 
Stock, W.D., Wienand, K.T. \& Baker, A.C. 1995. Impacts of invading $\mathrm{N}_{2}$-fixing Acacia species on patterns of nutrient cycling in two Cape ecosystems: evidence from soil incubation studies and ${ }^{15} \mathrm{~N}$ natural abundance values. Oecologia 101:375-382.

Thomson, G. \& Brundu, G. 2010. Alien trees in the Mediterranean countries: focussing on Acacia spp. Thematic workshop Session 1.2. In: Brunel, S., Uludag, A., Fernández-Galiano, E. \& Brundu, G. (eds.), Proceedings of the $2^{\text {nd }}$ International Workshop on Invasive Plants in the Mediterranean Type Regions of the World (Trabzon, Turkey, 02-06 August 2010): 22-23. [http://archives.eppo.int/MEETINGS/2010_conferences/ias_trabzon/Proceedings_Trabzon_Workshop.pdf].

Tinchieri, G. 1909. Arboricole di Sicilia (Tav. III). Bullettino dell'Orto Botanico della Regia Università di Napoli 2(2): 261-282.

Traveset, A., Brundu, G., Carta, L., Mprezetou, I., Lambdon, P., Manca, M., Médail, F., Moragues, E., Rodríguez-Pérez, J., Siamantziouras, S., Suehs, C.M., Troumbis, A., Vilà, M. \& Hulme, P.E. 2008. Consistent performance of invasive plant species within and among islands of the Mediterranean basin. Biological Invasions 10: 847-858.

Verloove, F. \& Reyes-Betancort, J.A. 2011. Additions to the flora of Tenerife (Canary Islands, Spain). Collectanea Botanica 30: 63-78.

Vilà, M., Meggaro, Y. \& Weber, E. 1999. Preliminary analysis of the naturalized flora of northern Africa. Orsis, 14: 9-20.

Vilà, M., Tessier, M., Suehs, C.M., Brundu, G., Carta, L., Galanidis, A. Lambdon, P., Manca, M., Médail, F., Moragues, E., Traveset, A.,
Troumbis, A.Y. \& Hulme, P.E. 2006. Local and regional assessment of the impacts of plant invaders on vegetation structure and soil properties of Mediterranean islands. Journal of Biogeography 33: 853-861.

Villari, R. \& Zaccone, R. 1999. Paraserianthes lophantha (Willd.) J. Nielsen (Mimosaceae) a new alien species naturalised to Sicily. Flora Mediterranea 9: 287-290.

Werner, C., Peperkorn, R., Máguas, C. \& Beyschlag, W. 2008. Competitive balance between the alien invasive Acacia longifolia and native Mediterranean species. In: Tokarska-Guzik, B., Brock, J.H., Brundu, G., Child, L., Daehler, C.C. \& Pyšek, P. (eds.), Plant invasions: Human perception, ecological impacts and management: 261-275. Backhuys Publishers, Leiden.

Whibley, D.J.E. \& Symon, D.E. 1992. Acacias of South Australia. Revised 2 ${ }^{\text {nd }}$ ed. Government Printer. South Australia.

Witkowski, E.T.F. 1991a. Effects of invasive alien acacias on nutrient cycling in the coastal lowlands of the Cape fynbos. Journal of Applied Ecology 28: 1-15.

Witkowski, E.T.F. 1991b. Growth and competition between seedlings of Protea repens (L.) L. and the alien invasive, Acacia saligna (Labill.) Wendl. in relation to nutrient availability. Functional Ecology 5: 101-110.

Zodda, G. 1903. Di alcuni nuovi casi teratologici. Malpighia XVII: 492-511.

Associate Editor: Javier Fuertes Received: 2-V-2012

Accepted: 13-XI-2012 